\title{
PENGARUH INSTAGRAM DALAM MEMBENTUK PERILAKU KONSUMTIF PADA MAHASISWA PROGRAM STUDI PENDIDIKAN EKONOMI UNIVERSITAS NUSANTARA PGRI KEDIRI
}

\author{
Eunike Rose Mita Lukiani ${ }^{1}$, Ayu Nur Rizka², Tjetjep Yusuf Afandi ${ }^{3}$, \\ Zainal Arifin ${ }^{4}$, Bayu Surindra ${ }^{5}$, Elis Irmayanti ${ }^{6}$, Efa Wahyu P7 \\ eunike-mita@unpkediri.ac.id¹ ${ }^{1}$, tetjepl@unpkediri.ac.id³ ${ }^{3}$,zainalarifin@unpkediri.ac.id ${ }^{4}$, \\ bayusurindra@unpkediri.ac.id5, elis@unpkediri.ac.id ${ }^{6}$,efawahyu@unpkdr.ac.id77 \\ 1,3,4,5,6,7Pendidikan Ekonomi \\ 1,3,4,5,6,7Universitas Nusantara PGRI Kediri
}

\begin{abstract}
Abstrak
Tujuan penelitian ini untuk mengetahui bahwa Instagram berkontribusi aktif dalam membentuk perilaku konsumsi mahasiswa pendidikan ekonomi, yang ternyata pengaruh ini belum disadari oleh mahasiswa Pendidikan Ekonomi Universitas Nusantara PGRI Kediri yang notabene didik menjadi guru ekonomi. Adapun metode penelitian ini Mix Method, kuantitatif dan Kualitataif. Data kuantitatif diperoleh melalui angket yang kemudian diolah uji korelasi sedangkan data kualitatif diperoleh melalui wawancara. Hasil penelitian menunjukkan bahwa terdapat 5 hal dalam Instagram yang memicu perilaku konsumtif mahasiswa Pendidikan Ekonomi Universitas Nusantara PGRI Kediri, diantaranya: 1)Durasi, 2)Frekuensi, 3)Following, 4)Follower, 5)Hal yang dinggah. Mengingat besarnya kerugian perilaku konsumsi yang irasional, maka hasil temuan ini penting untuk dipublikasikan
\end{abstract}

Kata kunci: Instagram, Perilaku konsumtif, Irasional, Mahasiswa Pendidikan Ekonomi

\section{PENDAHULUAN}

Fenomena saat ini adalah hampir semua remaja merupakan pengguna aktif instagram, termasuk mahasiswa Pendidikan Ekonomi Universitas Nusantara PGRI Kediri. Instagram adalah aplikasi digital yang berfungsi sebagai media sosial (Miranda \& Lubis, 2017). Yang dimaksud media sosial adalah teknologi yang digunakan untuk mengikat orang-orang ke dalam suatu kolaborasi, saling bertukar informasi dan berinteraksi melalui isi pesan yang berbasis digital. Bentuk tukar menukar informasi dan interaksi dalam instagram dapat berupa teks, gambar, suara dan video. Tukar menukar informasi dapat disaksikan secara bebas atau umum, baik disaksikan oleh perseorangan (individu), kelompok atau grup, maupun korporasi (Miranda \& Lubis, 2017).

Instagram kependekan dari kata "instan" dan "telegram". Kata "instan" atau "insta", seperti kamera polaroid yang dulu dikenal dengan "foto instan". Sedangkan untuk kata "gram" berasal dari kata "telegram", di mana cara kerja telegram adalah untuk mengirimkan informasi kepada orang lain dengan cepat. Dengan demikian Instagram mengandung arti dapat menampilkan foto-foto secara instan dan disampaikan dengan cepat (Miranda \& Lubis, 2017). Secara sederhana pengertian Instagram adalah situs jejaring sosial yang mengutamakan berbagi foto atau video kepada pengguna lainnya.

Berdasarkan observasi awal diketahui bahwa seluruh mahasiswa Pendidikan Ekonomi Universitas Nusantara PGRI pengguna Insatgram aktif dan termasuk golongan masyarakat usia remaja. Usia remaja adalah berkisar antara 17 sampai 23 tahun. (Kurniawan, 2017). Pada usia remaja 
berada dalam proses pembentukan jati diri sehingga sensitif terhadap pengaruh hal-hal luar (Haryani \& Herwanto, 2015). Iklan merupakan salah satu bentuk pengaruh dari luar. Apriliana \& Utomo (2019), mengungkapkan bahwa jika seseorang semakin lama dan semakin sering terpapar iklan, maka semakin besar peluang orang tersebut terpengaruh iklan. Dalam iklan terkandung bujukan dan rayuan yang memicu rasa tertarik. Jika seseorang semakin sering dan semakin lama terpapar iklan, maka semakin besar peluang orang tersebut mengkonsumsi barang atau jasa yang diiklankan.

Saat ini, instagram adalah salah satu bentuk sarana menampilkan iklan. Berbagai fasilitas dalam Instagram, membuat para produsen memperhitungkan Instagram sebagai sarana pemasaran (promosi) yang efektif dan efisien (Miranda \& Lubis, 2017). Dikatakan Efektif sebab produsen merasa Instagram berhasil menarik konsumen mengkonsumsi barang/ jasa yang diiklan. Dikatakan efisien, sebab melalui instagram, produsen dapat memasarkan produknya dengan: (1)Mudah, hanya dengan mengirim foto atau video produk yang dijual; (2)Biaya promosi murah, dengan anggaran terjangkau, hanya bermodalkan handphone sebagai media pengambil gambar / video dan kuota internet atau wifi untuk menggunggah iklan barang yang dijual dalam instagram maka produk sudah terpromosikan; (3)Pemasaran dapat dilakukan dengan cepat, asal terdapat jaringan internet dan kuota, maka iklan produk yang dijual dapat segera diterima konsumen; (4)Produsen bisa melakukan aktifitas pemasaran dimana saja, (5)Kapan saja, tidak terbatas waktu siang ataupun malam asalkan ada jaringan internet untuk mengunggah; (6)Dengan jangkauan promosi yang tidak terbatas jarak, lintas negara, lintas benua; dan (7)Tidak terbatas jumlah konsumen, berapapun jumlah konsumen bisa menerima iklan, selama konsumen tersebut mengakses Instagram (Miranda \& Lubis, 2017) (Apriliana \& Utomo, 2019).

Berangkat dari premis tersebut, peneliti ingin mengetahui apakah Instagram juga memiliki andil dalam membentuk perilaku konsumtif mahasiswa Pendidikan Ekonomi Universitas Nusantara PGRI Kediri. Hal ini penting diteliti sebab mahasiswa Pendidikan Ekonomi Universitas Nusantara PGRI Kediri adalah mahasiswa yang di-didik sebagai calon guru ekonomi, yang nantinya harus menjadi teladan dalam profesinya sebagai guru, serta dalam kehidupan berbangsa dan negara.

Sumartono (2005: 176) mendefinisikan perilaku konsumtif yaitu suatu perilaku yang tidak didasarkan pada pertimbangan rasional. Yang dimaksud pertimbangan tidak rasional adalah (1)pembelian impulsif yaitu pembelian secara tiba-tiba atau tidak berpikir panjang atau tidak memikirkan apa yang akan terjadi kemudian, (2)pemborosan yakni menghambur-hamburkan uang tanpa disadari kebutuhan yang jelas, (3)pembelian semata-mata untuk mencari kesenangan dan kepuasan, bisa karena hobi atau faktor yang lain (Lina, 2015: 04). Perilaku konsumtif cenderung mengarah pada perilaku negatif jika hal ini terus-menerus dibiarkan akan timbul rasa yang selalu kurang atau tidak cukup dengan apa yang dimilikinya. Perasaan yang selalu kurang dan tidak cukup dengan apa yang dimiliki bisa membuat individu menghalalkan segala cara untuk memenuhi perilaku konsumtifnya, termasuk cara tidak halal seperti mencuri, korupsi, menipu, memeras dan lain-lain (Mayasari, 2008).

\section{METODE PENELITIAN}

Penelitian ini menggunakan pendekatan Mix Method, yaitu gabungan kuantitatif dan Kualitataif. Data kuantitatif diperoleh melalui angket yang kemudian diolah dengan uji korelasi sedangkan data kualitatif diperoleh melalui wawancara. Kemudian data Mix Method dipaparkan dalam bentuk deskriptif untuk mengetahui pengaruh Instagram dalam membentuk perilaku konsumtif mahasiswa Pendidikan Ekonomi Universitas Nusantara PGRI Kediri. Adapun pendekatan Kunatitatif untuk memperoleh data yang berkaitan dengan angka, yang dalam penelitian ini diantaranya tentang: 1)Lama durasi menggunakan Instagram, 2)Keseringan frekuensi membuka Instagram, 3)Jumlah Follower. Sedangkan pendekatan kuantitatif diperoleh melalkui wawancara untuk mengetahui: 1)Jenis following/ akun yang diikuti mahasiswa Pendidikan Ekonomi Universitas Nusantara PGRI Kediri, 2)Hal-hal yang diunggah oleh mahasiswa Pendidikan Ekonomi Universitas Nusantara PGRI Kediri. Jumlah responden penelitian ini adalah 43 orang mahasiswa 


\section{PEMBAHASAN}

Peran Instagram dalam Membentuk Perilaku Konsumtif pada mahasiswa program studi pendidikan ekonomi Universitas nusantara pgri kediri

1. Durasi.

- Durasi adalah rentang waktu atau lama-nya waktu yang dihabiskan seseorang untuk menikmati Instagram.

- Semakin panjang durasi atau semakin lama waktu yang dihabiskan untuk menikmati instagram, maka semakin besar juga peluang orang tersebut berkonsumsi irasional.

- Pernyataan tersebut diperoleh dari hasil uji korelasi hubungan (Pearson Correlation) konsumsi dengan durasi sebesar 0,895 (lihat gambar 2).

- Nilai Pearson Correlation 0,895 menandakan hubungan yang sangat kuat. Sebab rentang nilai dalam Pearson Correlation adalah 0 sampai 1. Jika Pearson Correlation bernilai 1 maka artinya memiliki hubungan yang sempurna, jika Pearson Correlation bernilai 0 maka arinya tidak ada hubungan sama sekali. Sedangkan dari uji korelasi (gambar 2) diketahui bahwa nilai Pearson Correlation konsumsi dengan durasi bernilai 0,895 . Artinya konsumsi dengan durasi memiliki hubungan erat. nilai 0,895 telah melebihi 0,5 dan mendekati nilai 1 .

\section{Frekuensi.}

- Frekuensi adalah kekerapan atau keseringan seseorang mengakses Instagram.

- Semakin sering frekuensi seseorang menikmati Instagram, semakin besar pula peluang orang tersebut berperilaku konsumsi irasional.

- Pernyataan tersebut diperoleh dari hasil uji korelasi hubungan (Pearson Correlation) konsumsi dengan frekuensi sebesar 0,860 (lihat gambar 2).

- Nilai Pearson Correlation 0,860 menandakan hubungan yang sangat kuat. Sebab rentang nilai dalam Pearson Correlation adalah 0 sampai 1. Jika Pearson Correlation bernilai 1 maka artinya memiliki hubungan yang sempurna, jika Pearson Correlation bernilai 0 maka arinya tidak ada hubungan sama sekali. Sedangkan dari uji korelasi (gambar 2) diketahui bahwa nilai Pearson Correlation konsumsi dengan frekuensi bernilai 0,860. Artinya konsumsi dengan durasi memiliki hubungan erat. nilai 0,860 telah melebihi 0,5 dan mendekati nilai 1

\begin{tabular}{|c|c|c|c|c|}
\hline \multicolumn{5}{|c|}{ Correlations } \\
\hline & & Konsumsi & Durasi & Frekuensi \\
\hline \multirow[t]{3}{*}{ Konsumsi } & Pearson Correlation & 1 & $.895^{\star \star}$ & $.860^{* *}$ \\
\hline & Sig. (2-tailed) & & .000 & .000 \\
\hline & $\mathrm{N}$ & 43 & 43 & 43 \\
\hline \multirow[t]{3}{*}{ Durasi } & Pearson Correlation & $.895^{\star *}$ & 1 & $.887^{\star \star}$ \\
\hline & Sig. (2-tailed) & .000 & & .000 \\
\hline & $\mathrm{N}$ & 43 & 43 & 43 \\
\hline \multirow[t]{3}{*}{ Frekuensi } & Pearson Correlation & $.860^{* *}$ & $.887^{\star \star}$ & $\overline{1}$ \\
\hline & Sig. (2-tailed) & .000 & .000 & \\
\hline & $\mathrm{N}$ & 43 & 43 & 43 \\
\hline
\end{tabular}

Gambar 1. Hasil Uji Korelasi Besar Konsumsi dengan Durasi dan Frekuensi Menggunakan Instagram Sumber: (Rizka et al., 2019) 


\section{Following.}

- Following merupakan pengguna instagram yang kita ikuti aktivitasnya. Following dapat berupa individu perseorangan, kelompok atau grup atau club, badan atau instansi atau lembaga, korporasi atau perusahaan, konten, dan lain-lain.

- Hubungan following dengan perilaku konsumsi tidak rasional adalah, terdapat aktifitas tertentu dari akun-akun tertentu yang kita ikuti (following) yang dapat memicu seseorang berkonsumsi irasional.

- Berdasarkan hasil penelitian, konten yang diikuti (follow) oleh mahasiswa Pendidikan Ekonomi Universitas Nusantara PGRI diantaranya adalah fotografi, healty life, lagu, Quote, K-Pop, Fashion, Humor, Kuliner, Berita terkini (ditunjukkan dalam gambar 3).

- Berdasarkan hasil angket diketahui bahwa tayangan tertentu dalam konten yang diikuti dapat memicu seseorang berkonsumsi irasional

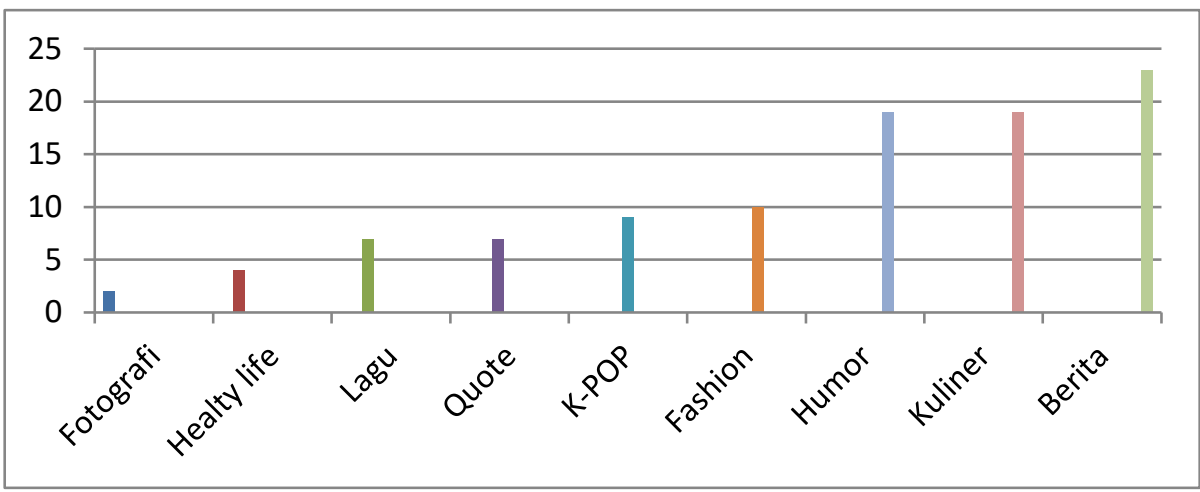

Gambar 2. Prosentase Konten Instagram yang Diikuti Mahasiswa Pendidikan Ekonomi Universitas Nusantara PGRI Kediri, Sumber: (Rizka et al., 2019)

\section{Follower.}

- Follower adalah pengguna lain Instagram yang mengikuti aktivitas kita di instagram. Sama halnya dengan Following, follower yang mengikuti aktifitas kita dapat berupa individu perseorangan, kelompok/grup, badan/instansi, korporasi/perusahaan, konten, dan lain-lain. Follower yang mengikuti aktifitas kita di Instagram tidak dibatasi jumlahnya, dan bebas berinteraksi mengirim pesan pada kita.

- Berdasarkan hasil angket dan wawancara mendalam diketahui terdapat hubungan antara perilaku konsumsi yang tidak rasional dengan follower. Hubungan tersebut adalah terdapat perilaku follower tertentu yang memicu Following (pengguna Instagram yang diikuti aktifitasnya) bertindak tidak rasional dalam berkonsumsi.

- Adapun perilaku follower yang memicu konsumsi tidak rasional misalnya dalam bentuk komentar. Bisa dalam bentuk komentar positif (pujian, kekaguman, suka atau like) maupun komentar negatif seperti ejekan, bully, dan lain-lain. Untuk mendapatkan komentar positif following rela bertindak rasional dalam berkonsumsi. 


\section{Hal yang diunggah.}

- Setiap pengguna Instagram memiliki fasilitas untuk menggunggah statusnya. Status dapat berupa kata-kata, photo, video maupun siaran langsung.

- Frekuensi seseorang menggungah status tidak ada batasan. Seseorang bisa saja menggungah statusnya setiap jam, setiap menit, tanpa ada batasan.

- Perilaku konsumtif ternyata berkaitan erat dengan aktifitas yang diunggah. Terdapat unggahan tertentu yang memicu perilaku konsumsi irasional. Misalnya, 1)Unggahan untuk menunjukkan dalam keadaan berkelimpahan, 2)Unggahan untuk menunjukkan kemampuan yang dimiliki, 3)Unggahan yang menunjukkan kelebihan fisik seperti bentuk tubuh yang menarik, wajah yang cantik / tampan, 4)Unggahan yang menunjukkan kepemilikan materi atau atribut, 5)Dan unggahan yang berorientasi untuk mendapatkan pujian dan ketenaran di media social. Dari berbagai motivasi unggahan tersebut memicu seseorang (following) bertindak konsumsi irasional.

- Berdasarkan hasil angket, hal-hal yang diunggah oleh mahasiswa pendidikan ekonomi Universitas Nusantara PGRI adalah seputar aktifitas sehari-hari seperti 1)Pergi ke tempat wisata (rekreasi), 2)Makan di luar bersama teman atau keluarga, 3)Kegiatan berbelanja (shoping), 4)kegiatan di kampus (suasana di kelas, belajar bersama teman, saat presentasi dII), 5)Mengikuti perlombaan / kompetisi, 6)Prestasi yang diraih, 7)Saat melakukan hobi (bersepeda, memancing, olahraga, dll), 8)kata-kata motivasi, 9)curahan hati, dan lain-lain. (Rizka et al., 2019)

Dari kelima hal tersebut: 1)Lamanya Durasi, 2)Frekuensi mengakses Instagram, 3)Jumlah Follower, 4)Jenis konten Instagram yang kita ikuti/Following, 5)Hal yang diunggah, memicu perilaku konsumsi. Perilaku konsumsi sendiri terdiri dari dua macam yakni perilaku konsumsi yang rasional dan perilaku konsumsi yang tidak rasional (irasional). Tidak selalu Instagram membuat seseorang menjadi berperilaku konsumsi tidak rasional. Perilaku konsumsi dikatakan rasional jika kegiatan konsumsi didasarkan pada kebutuhan, bukan keinginan, ketepatan guna, waktu, tempat, kemampuan pada porsinya (Kurniawan, 2017)

Perilaku konsumsi dikatakan tidak rasional (irasional) jika mengandung salah satu dari ciri-ciri berikut, ciri perilaku konsumtif (Haryani \& Herwanto, 2015), (Miranda \& Lubis, 2017)

a. Pembelian impulsif (Impulsive Buying)

Pembelian impulsif adalah pembelian yang dilakukan secara tiba-tiba, atau tidak berpikir panjang dalam membeli. Yang dimaksud tidak berpikir panjang adalah tidak memikirkan dampak yang akan terjadi kemudian.

b. Konsumsi tidak rasional (Non rational buying)

Konsumsi yang tidak rasional yakni konsumsi yang diluar kemampuan keuangan, konsumsi untuk memperoleh pengakuan/ status, meniru idola, dan konsumsi sebagai pelarian dari masalah atau kesenangan

c. Pemborosan (Wastafel Buying) yakni konsumsi yang tidak sesuai dengan jumlah kebutuhan yang diperlukan.

Jika seseorang dalam melakukan konsumsi setidaknya terdapat satu alasan dari motif tersebut (Impulsive Buying, Non rational buying, Wastafel Buying), maka dapat dikatakan orang tersebut tidak rasional dalam berkonsumsi. Temuan penelitian, secara garis besar ditunjukkan dalam gambar 2 berkut. 


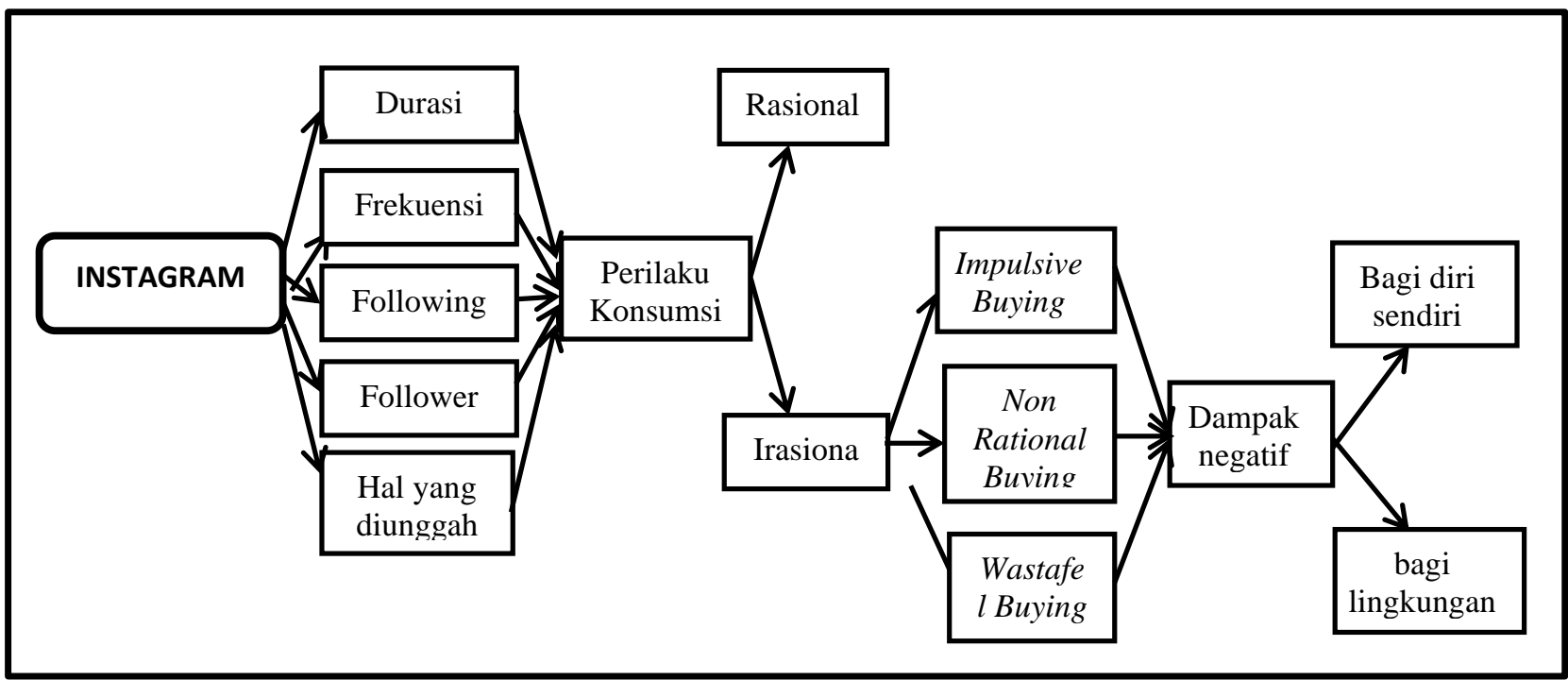

Gambar 3. Peran instagram dalam membentuk perilaku konsumsi Sumber: (Rizka et al., 2019)

\section{SIMPULAN}

Berdasarkan paparan di atas dapat disimpulkan bahwa:

1. Semakin panjang durasi/ waktu yang dihabiskan untuk mengakses Instagram, semakin tinggi kecenderungan mahasiswa Pendidikan Ekonomi Universitas Nusantara PGRI Kediri berperilaku Konsumtif

2. Semakin sering frekuensi mahasiswa Pendidikan Ekonomi Universitas Nusantara PGRI Kediri mengakses Instagram, semakin tinggi kecenderungan mahasiswa Pendidikan Ekonomi Universitas Nusantara PGRI Kediri berperilaku konsumtif

3. Semakin banyak follower atau pengikut yang mengikuti akun mahasiswa Pendidikan Ekonomi Universitas Nusantara PGRI Kediri, maka semakin tinggi pula kecenderungan mahasiswa Pendidikan Ekonomi Universitas Nusantara PGRI Kediri untuk berperilaku konsumtif. Apalagi jika follower atau pengikutnya memberikan komentar pada hal yang diunggah. Komentar seputar penilaian baik penilaian positif (pujian) maupun penilaian negatif (kritikan), keduanya sama-sama memicu perilaku konsumtif. Pada komentar positif, mahasiswa akan merasa puas dan bangga, sehingga memicu mahasiswa mempertahankan pujian follower yang salah satunya diwujudkan dengan meningkatkan konsumsinya/ penampilannya. Pada komentar negatif, mahasiswa merasa tertantang untuk membuktikan/menunjukkan penampilan terbaik (unggahan). Rasa tertantang dan haus pengakuan ini kemudian juga memicu perilaku konsumtif.

4. Terdapat jenis tertentu (Following) yang memicu perilaku konsumtif. Misalnya fashion terkini, tutorial makeup, K-Pop, Kuliner, Life style dan lain-lain. Baik secara sadar maupun tidak, mahasiswa Pendidikan Ekonomi Universitas Nusantara PGRI Kediri menjadi terinspirasi untuk mengikuti gaya, trend, dan model yang dilihatnya dalam Instagram.

5. Pada jenis konten yang diunggah mahasiswa Pendidikan Ekonomi Universitas Nusantara PGRI Kediri, terdapat unggahan-unggahan tertentu yang memicu mahasiswa menjadi konsumtif. Misalnya, jenis unggahan berupa hangout makan bersama teman. Mahasiswa memikirkan atribut yang dikenakan, tempat lokasi pengambilan gambar, makan yang sedang dimakan, dan lain-lain. Hal-hal inilah yang pada akhirnya memicu mahasiswa berperilaku konsumtif. Jenis unggahan lain yang juga memicu perilaku konsumtif diantaranya, aktifitas sehari-hari, aktifitas saat berolahraga, pergi ke tempat rekreasi, aktifitas yang menunjukkan ketika berbelanja, dan lain-lain 


\section{SARAN PENGEMBANGAN PENELITIAN LANJUT (FUTURE RISET)}

Mengingat besarnya keburukan yang dapat timbul dari perilaku konsumtif, maka penting sekali untuk menindaklanjuti hasil penelitian ini dengan: 1)Sosialisasi kepada pelajar di seluruh jenjang pendidikan (SD, SMP, SMA, Perguruan Tinggi) tentang pengaruh Instagram dalam memicu perilaku konsumtif, sebab saat ini Instagram bukan hanya dimiliki oleh mahasiswa, tetapi semua jenjang usia, bahkan sejak anak-anak (usia SD). 2)Memperluas kajian pengaruh madia sosial lainnya dalam membentuk perilaku konsumtif, misalnya Facebook, What App Grup, dll. 3)Memperdalam pengamatan dan analisis dampak perilaku konsumtif pada individu dalam jangka Panjang. 4)Memperluas subyek penelitian, responden bukan hanya mahasiswa, namun berbagai jenjang usia sesuai jenjang pendidikannya (usia SD, SMP, dan SMA) sehingga dapat menemukan karakteristik perilaku konsumtif pada tiap jenjang usia.

\section{DAFTAR PUSTAKA}

Apriliana, N. S., \& Utomo, P. U. (2019). Pengaruh Intensitas Melihat Iklan di Instagram terhadap Pengetahuan dan Perilaku Konsumtif Remaja Putri. Jurnal Komunikasi, 13(2), 179-190.

Haryani, I., \& Herwanto, J. (2015). Hubungan Konformitas dan Kontrol Diri Dengan Perilaku Konsumtif Terhadap Produk Kosmetik pada Mahasiswi. Jurnal Psikologi, 11(1), 5-11.

Jumlah Mahasiswa Pendidikan Ekonomi Universitas Nusantara PGRI Kediri. Tersedia: https://googleweblight.com/i?u=https://forlap.ristekdikti.go.id/perguruantinggi/deta il/RjVEOERCMTItQklwMC00ODQ5LUE3NUUtMTI2ODQzQTdEQjM1\&hl=idID. (Online). Diunduh 24 Juni 2020

Kamus Besar Bahasa Indonesia. Diakses 25 mei 2020, dari http://www.

http://kbbi.web.id/

Kurniawan, C. (2017). Analisis Faktor-Faktor Yang Mempengaruhi Perilaku Konsumtif Ekonomi Pada Mahasiswa. Jurnal Media Wahana Ekonomika, 13(4), 107-118.

Miranda, S., \& Lubis, E. E. (2017). Pengaruh Instagram Sebagai Media Online Shopping Fashion Terhadap Perilaku Konsumtif Mahasiswa Fakultas Ilmu Sosial dan Ilmu Politik Universita Riau. JOM FISIP, 4(1), 1-15.

Rizka, A. N., Afandi, T. Y., \& Lukiani, E. R. M. (2019). Hubungan Instagram dengan Perilaku Konsumtif Mahasiswa Pendidikan Ekonomi Universitas Nusantara PGRI Kediri. Efektor, 6(2), 1-9.

Surindra Bayu, Widyaningrum Bakti dan Zulistiani. (2017). Statistika Teori dan Praktik SPSS. Malang: CV. Azizah Publishing

Sumartono. 2005. Terperangkap dalam Iklan : Meneropong Imbas Pesan Iklan Televisi. Bandung: Alfabeta. 